\title{
Investigating the role of entrepreneurship governmental groups on macro-economic strategies
}

\author{
Asadollah Kordnaeij ${ }^{\mathrm{a}^{*}}$ and Mohsen Ebrahimi ${ }^{\mathrm{b}}$
}

${ }^{a}$ Associate Professor, Department of Management, Tarbiat Modarres University, Tehran, Iran ${ }^{b}$ Phd student, Department of Management, Tarbiat Modarres University, Tehran, Iran

\section{H R O N I C L E}

Article history:

Received July 18, 2014

Accepted December 182014

Available online

December 232014

Keywords:

Knowledge based organizations

Entrepreneurship governmental

groups

Technology-based economy

\begin{abstract}
A B S T R A C T
In recent years, there have been significant changes on governmental agencies than any other organizations. There is also an agreement that any improvement on economy requires an efficient government. Governments must be responsive against their people and society but there are evidences that many governmental agencies are not able to meet people's needs despite access to financial resources because of lack of entrepreneurial approach. This paper presents an empirical investigation to study the role of entrepreneurship governmental groups on macro-economic strategies. The study uses structural equation modeling, by designing a questionnaire in Likert scale, and distributes it among 384 randomly selected university professors in city of Tehran, Iran. The results confirm that technology-based economy, creative human resources and training, competition in the economic environment, knowledge creation, dissemination and application and promoting a culture of innovation and entrepreneurship influence positively on entrepreneurship governmental groups. In addition, the positive effects of entrepreneurship governmental groups on national commitment and management are confirmed.
\end{abstract}

\section{Introduction}

During the past few years, there have been tremendous changes on how governments manage countries. Electronic governments have reduced the cost of accomplishment of tasks, significantly and there are many studies associated with it (Kreiser et al., 2002; Nicholson \& de Waal-Andrews, 2005; Gartner, 2007). Diller (2000), for instance, investigated the changes in the administrative structure of the welfare system occurred over the period 1996-2000. Audretsch and Thurik (2004) dealt with the distinction between the models of the managed and entrepreneurial economies (Hayton et al., 2002). They described why the model of the entrepreneurial economy (Creswell, 2002; Sarasvathy \& Venkataraman, 2011) could be a better frame of reference than other methods. During the past few years, entrepreneurship re-emerged as a key agenda item of economic policy-makers across Europe (Hayton et al., 2002).

\footnotetext{
* Corresponding author

E-mail address: naiej@modares.ac.ir (A. Kordnaeij)

(C) 2015 Growing Science Ltd. All rights reserved. doi: $10.5267 /$ j.uscm.2014.12.011
} 
According to Duane Ireland and Webb (2007), in today's fast-paced competitive environment, most companies encounter the need to be increasingly nimble and adaptive. They discussed strategic entrepreneurship as the means through which companies concurrently exploit their current competitive advantages while exploring for future opportunities. Reaching a balance between exploration and exploitation consists of more than merely assigning resources evenly between the two processes. According to Verheul et al. (2002), the issue of entrepreneurship has evolved over time and many small business clearly changed. Thurik and Wennekers (2004) looked at the relationship between small business and entrepreneurship as well as the differences between the two and reported that entrepreneurship in small firms happen more frequently.

\section{The proposed method}

This paper presents an empirical investigation to study the role of entrepreneurship governmental groups on macro-economic strategies. The study uses structural equation modeling, by designing a questionnaire with 36 questions in Likert scale, and distributes it among some randomly selected university professors in city of Tehran, Iran. The population of this survey includes all experts in governmental agencies and the sample size is calculated as follows,

$$
N=Z_{\alpha / 2}^{2} \frac{p \times q}{e^{2}},
$$

where $N$ is the sample size, $p=1-q$ represents the probability, $z_{\alpha / 2}$ is CDF of normal distribution and finally $\varepsilon$ is the error term. For our study we assume $p=0.5, z_{\alpha / 2}=1.96$ and $e=0.05$, the number of sample size is calculated as $N=384$. Fig. 1 shows personal characteristics of the participants.

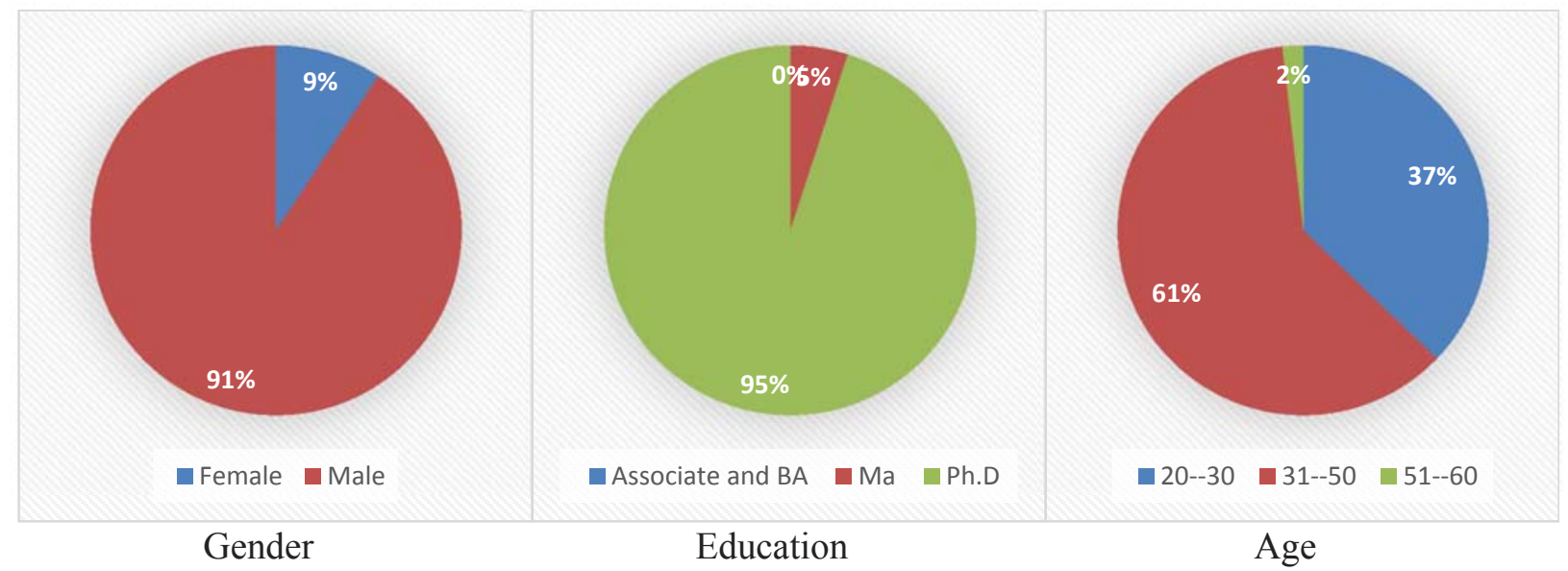

Fig. 1. Personal characteristics of the participants

As we can observe from the results of Fig. 1, most participants were middle-age male with high level of educations. In addition, Fig. 2 shows the framework of the proposed study. As we can observe from the structure of Fig. 2, there are three main hypotheses associated with the proposed study of this paper. In addition, the first hypotheses itself consists of five sub-hypotheses.

$\mathrm{H}_{1}$ : Components of knowledge based economy (Brinkley, 2006) influences positively on entrepreneurship governmental groups.

$\mathrm{H}_{1-1}$ : Technology-based economy influences positively on entrepreneurship governmental groups.

$\mathrm{H}_{1-2}$ : Creative human resources and training influences positively on entrepreneurship governmental groups. 
$\mathrm{H}_{1-3}$ : Competition in the economic environment influences positively on entrepreneurship governmental groups.

$\mathrm{H}_{1-4}$ : Knowledge creation influences positively on entrepreneurship governmental groups.

$\mathrm{H}_{1-5}$ : Dissemination and application and promoting a culture of innovation and entrepreneurship influence positively on entrepreneurship governmental groups.

In addition, there are two other main hypotheses associated with the proposed study of this paper as follows,

$\mathrm{H}_{2}$ : Entrepreneurship governmental groups influence positively on national commitment.

$\mathrm{H}_{3}$ : Entrepreneurship governmental groups influence positively on management efforts.

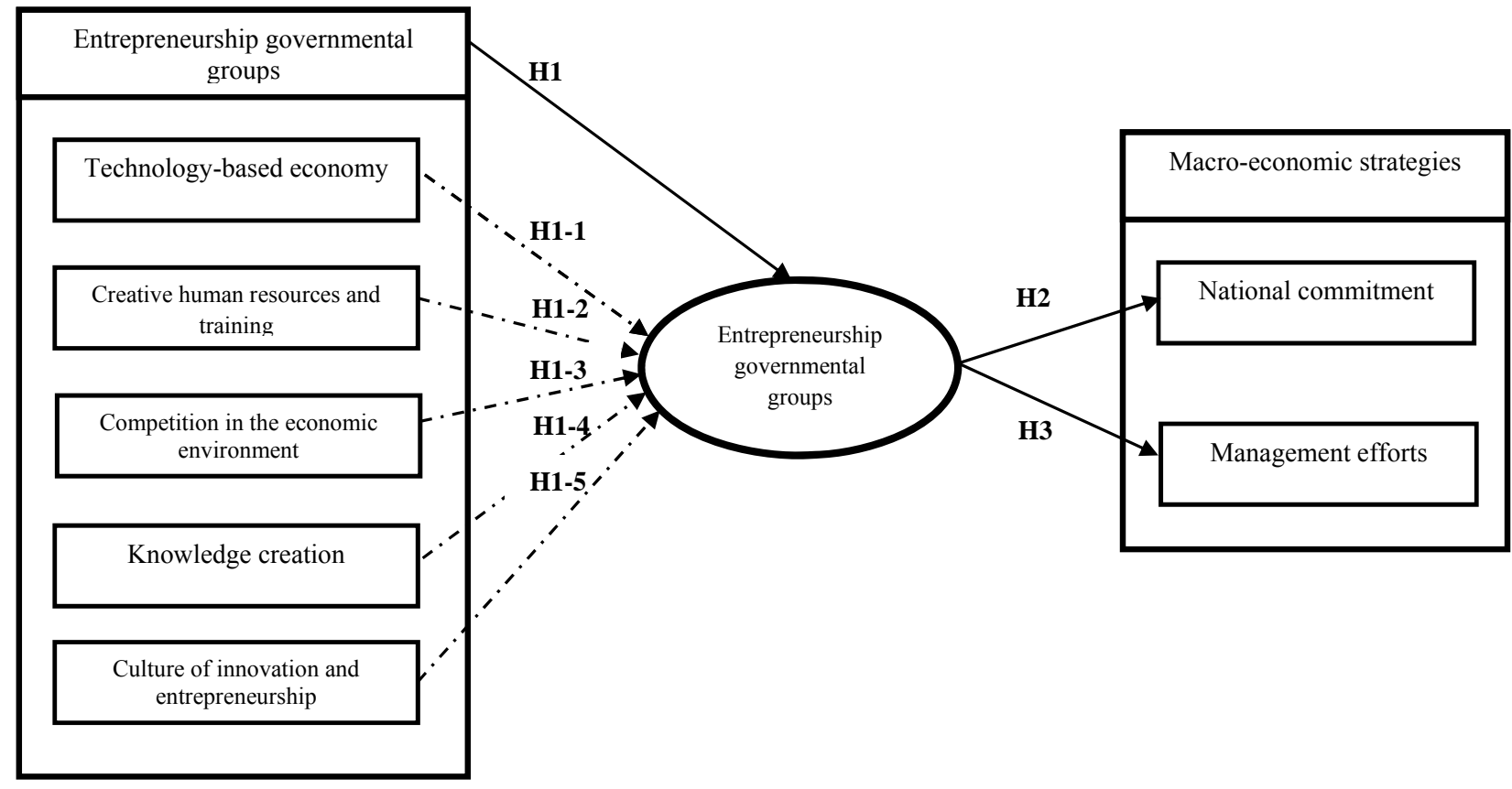

Fig. 2. The proposed study

The proposed study of this paper has applied structural equation modeling (SEM) to verify different hypotheses of this survey. Table 1 demonstrates some basic statistics associated with SEM implementation.

\section{Table 1}

The summary of some basic statistics

\begin{tabular}{clcccc}
\hline No & Description & No. of Q. & Factor loading & Cronbach alpha & AVE $^{1}$ \\
\hline 1 & Technology-based economy & 3 & 0.56 & 0.755 & 0.62 \\
2 & Creative human resources and training & 2 & 0.61 & 0.801 & 0.58 \\
3 & Competition in the economic environment & 2 & 0.56 & 0.840 & 0.52 \\
4 & Knowledge creation & 3 & 0.59 & 0.855 & 0.51 \\
5 & Culture of innovation and entrepreneurship & 3 & 0.62 & 0.720 & 0.54 \\
6 & Entrepreneurship governmental groups & 13 & 0.63 & 0.835 & 0.76 \\
7 & National commitment & 5 & 0.57 & 0.772 & 0.62 \\
8 & Management efforts & 5 & 0.54 & 0.801 & 0.54 \\
\hline 1Average Variance Extracted & & & &
\end{tabular}


As we can observe from the results of Table 1, Cronbach alpha values for all components of the survey are well above the minimum desirable level, which confirms the overall questionnaire. In addition, factor loadings and average variance extracted are also within acceptable levels. Table 2 shows details of other necessary statistics.

Table 2

The summary of some other statistics

\begin{tabular}{lcc}
\hline Statistics & Value & Desirable level \\
\hline Chi-Square/df & 2.61 & $<3.0$ \\
Goodness-of-fit (GFI) & 0.92 & $>0.90$ \\
Root Mean Square Error of Approximation (RMSEA) & 0.071 & $<0.09$ \\
Confirmatory Fit Index (CFI) & 0.90 & $>0.90$ \\
Adjusted goodness-of-fit index (AGFI) & 0.94 & $>0.80$ \\
Normed Fit Index (NFI) & 0.93 & $>0.90$ \\
Non-Normed Fit Index (NNFI) & 0.95 & $>0.90$ \\
\hline
\end{tabular}

The results of Table 2 also confirm that all statistics are within desirable values. Therefore, we use SEM results to examine the hypotheses.

\section{The results}

In this section, we present details of our findings on testing various hypotheses of the survey. We first present the results of correlation among different components of the survey in Table 3 as follows,

Table 3

The summary of correlation ratios among various components

\begin{tabular}{|c|c|c|c|c|c|c|c|c|c|}
\hline No & Description & 1 & 2 & 3 & 4 & 5 & 6 & 7 & 8 \\
\hline 1 & Technology-based economy & $1.00^{* * *}$ & & & & & & & \\
\hline 2 & Creative human resources and training & $0.65^{* *}$ & $1.00^{* *}$ & & & & & & \\
\hline 3 & Competition in the economic environment & $0.56^{* *}$ & $0.69^{* *}$ & $0.52^{* *}$ & $1.00^{* *}$ & & & & \\
\hline 4 & Knowledge creation & $0.54^{* *}$ & $0.57^{* *}$ & $0.63^{* *}$ & $0.56^{* *}$ & $1.00^{* *}$ & & & \\
\hline 5 & Culture of innovation and entrepreneurship & $0.63^{* *}$ & $0.55^{* *}$ & $0.59^{* *}$ & $0.52^{* *}$ & $0.43^{* *}$ & $1.00^{* *}$ & & \\
\hline 6 & Entrepreneurship governmental groups & $0.71^{* *}$ & $0.66^{* *}$ & $0.72^{* *}$ & $0.60^{* *}$ & $0.63^{* *}$ & $0.62^{* *}$ & $1.00^{* *}$ & \\
\hline 7 & National commitment & & & & & & & & \\
\hline 8 & Management efforts & $0.52^{* *}$ & $0.61^{* *}$ & $0.55^{* *}$ & $0.71^{* *}$ & $0.64^{\text {** }}$ & $0.52^{* *}$ & $0.57^{* * *}$ & $1.00^{* * *}$ \\
\hline
\end{tabular}

As we can observe from the results of Table 3, there are positive correlations among different pairs of the variables of the survey when the level of significance is five percent. Finally, Table 4 presents the results of path coefficients along with t-student values.

\section{Table 4}

The summary of testing various hypotheses of the survey

\begin{tabular}{llcccc}
\hline \multicolumn{2}{l}{ Hypotheses Description } & $\beta$ & $\mathrm{t}$-value & $\mathrm{R}^{2}$ & $\mathrm{Result}$ \\
\hline $\mathrm{H}_{1}$ & (Knowledge based economy $\rightarrow$ entrepreneurship governmental groups) & 0.44 & 7.588 & 0.54 & Confirmed \\
$\mathrm{H}_{2}$ & (Entrepreneurship governmental groups $\rightarrow$ National commitment) & 0.49 & 9.56 & 0.50 & Confirmed \\
$\mathrm{H}_{3}$ & (Entrepreneurship governmental groups $\rightarrow$ Management efforts) & 0.51 & 4.54 & 0.37 & Confirmed \\
$\mathrm{H}_{1-1}$ & (Technology based economy $\rightarrow$ entrepreneurship governmental groups) & 0.44 & 4.97 & 0.57 & Confirmed \\
$\mathrm{H}_{1-2}$ & (Creative human resources and training $\rightarrow$ entrepreneurship governmental groups) & 0.57 & 4.02 & 0.57 & Confirmed \\
$\mathrm{H}_{1-3}$ & (Competition $\rightarrow$ entrepreneurship governmental groups) & 0.62 & 4.37 & 0.57 & Confirmed \\
$\mathrm{H}_{1-4}$ & (Knowledge creation $\rightarrow$ entrepreneurship governmental groups) & 0.46 & 3.77 & 0.57 & Confirmed \\
$\mathrm{H}_{1-5}$ & (Culture of innovation $\rightarrow$ entrepreneurship governmental groups) & 0.40 & 3.99 & 0.57 & Confirmed \\
\hline
\end{tabular}

\section{Discussion and Conclusion}

In today's world, entrepreneurship as a viable strategy for the development of economy is the primary principle for human resources development. Great achievements stemming from entrepreneurship is essential flourishing factor for mobility, reliability, sustainability and economic viability of 
communities in different countries. The identification of human capacities in entrepreneurship and their applications in various areas of social life are considered as appropriate methods for development of economy. In recent years, there have been tremendous changes on governmental agencies and there has been an agreement among experts that any improvement on economy needs an efficient government. This paper has presented a survey to study the role of entrepreneurship governmental groups on macro-economic strategies. Using structural equation modeling, the study has confirmed that technology-based economy, creative human resources and training, competition in the economic environment, knowledge creation, dissemination and application and promoting a culture of innovation and entrepreneurship could influence positively on entrepreneurship governmental groups. In addition, the positive effects of entrepreneurship governmental groups on national commitment and management have also been confirmed.

According to the results of our survey, government must promote the culture of participatory management within organizations and institutions and people must be shared in all decision making procedures. Government must use tools such as the public trust, cooperation, solidarity and harmony among people, remove all unnecessary boundaries and focus on transparency and openness. The country's educational system must be improved and people must learn more about continuous learning advantages. Government must create an enabling environment for economic activity and investment through competition and economic security.

The survey could be applied for non-governmental agencies (Soysekerci \& Erturgut, 2010) by making some changes on the proposed model, which could considered for future researches. We may also look at the effects of culture and innovation on government policy making similar to the work accomplished by Turró et al. (2013) and we leave it for interested researchers as future works.

\section{Acknowledgement}

The authors would like to thank the anonymous referees for constructive comments on earlier version of this work.

\section{References}

Audretsch, D. B., \& Thurik, A. R. (2004). A model of the entrepreneurial economy. International Journal of Entrepreneurship Education, 2(2), 143-166.

Brinkley, I. (2006). Defining the knowledge economy. London: The work foundation, 19.

Creswell, J. W. (2002). Educational research: Planning, conducting, and evaluating quantitative. Prentice Hall.

Diller, M. (2000). The revolution in welfare administration: rules, discretion \& entrepreneurial government. As published in New York University Law Review, 75.

Duane Ireland, R., \& Webb, J. W. (2007). Strategic entrepreneurship: Creating competitive advantage through streams of innovation. Business Horizons, 50(1), 49-59.

Gartner, W. B. (2007). Is There an Elephant in Entrepreneurship? Blind Assumptions in Theory Development. In Entrepreneurship (pp. 229-242). Springer Berlin Heidelberg.

Hayton, J. C., George, G., \& Zahra, S. A. (2002). National culture and entrepreneurship: A review of behavioral research. Entrepreneurship Theory and Practice, 26(4), 33-52.

Kreiser, P. M., Marino, L. D., \& Weaver, K. M. (2002). Assessing the psychometric properties of the entrepreneurial orientation scale: A multi-country analysis. Entrepreneurship Theory and Practice, 26(4), 71-94.

Nicholson, N., \& de Waal-Andrews, W. (2005). Playing to win: Biological imperatives, self-regulation, and trade-offs in the game of career success. Journal of Organizational Behavior, 26(2), 137-154.

Sarasvathy, S. D., \& Venkataraman, S. (2011). Entrepreneurship as method: open questions for an entrepreneurial future. Entrepreneurship Theory and Practice, 35(1), 113-135. 
Soysekerci, S., \& Erturgut, R. (2010). Improvement of non-governmental organization entrepreneurship in vocational schools: Turkey case. Procedia-Social and Behavioral Sciences, 2(2), 1849-1854.

Thurik, R., \& Wennekers, S. (2004). Entrepreneurship, small business and economic growth. Journal of Small Business and Enterprise Development, 11(1), 140-149.

Turró, A., Urbano, D., \& Peris-Ortiz, M. (2013). Culture and innovation: the moderating effect of cultural values on corporate entrepreneurship. Technological Forecasting and Social Change, 88, 360-369.

Verheul, I., Wennekers, S., Audretsch, D., \& Thurik, R. (2002). An eclectic theory of entrepreneurship: policies, institutions and culture. InEntrepreneurship: Determinants and policy in a European-US comparison (pp. 11-81). Springer US. 